M. ROSNER, B. KA VCIC, A. S. TANNENBAUM, M. VIANELLO, and G. WEISER*

\title{
Worker Participation and Influence in Five Countries
}

The RISE OF DEOLOGICAL and political demands for increased participation in decision making by members of work organizations gives a particular significance to empirical research on workers' participation in decision making in industrial plants. In this article, we report results concerning workers' participation in decision making and its effects in 52 industrial plants in five countries: Austria, Israel, Italy, United States, and Yugoslavia. ${ }^{1}$ Two of the systems, the Yugoslav and kibbutz (Israel), have highly participative formal structures. Plants in the other countries-Austria, Italy, and the United States-have no formal worker representation mechanisms, but some degree of workers' participation in decision making may occur depending on the managers' leadership styles or on the existence in some cases of other devices of worker representation.

Data were obtained concerning first the relationships among the 52 plants between (1) workers' participation in decision making and (2) managerial and worker influence. These primary relationships were then examined using superior-subordinate communications, workers' trust in management, workers' sense of responsibility, and workers' personal influence as intervening variables. A general conclusion is that the enhanced influence that accompanies workers' participation in decision making within the plants in this study may be explained in part by the increased influence, trust, and responsibility felt by workers.

\footnotetext{
* The authors are, respectively, Former Director of Research, Givat Haviva Social Research Centre on the Kibbutz; Director of Research, Central Trade Union Organization of Slovenia; Professor of Psychology, and Program Director, Institute for Social Research, University of Michigan; Professor of Sociology, University of Rome; and Professor of Sociology, University of Vienna.

1 The authors would like to thank the Ford Foundation and the National Science Foundation for support in this research.
} 


\section{Workers' Participation}

One of the major difficulties of doing research on workers' participation is the variety of forms through which participation may occur. Is there a common denominator, for example, among the normative theories of participative management developed mainly by American social scientists ${ }^{2}$ and directed primarily at leadership style, the West European system of workers' formal representation in management, the Yugoslav system of selfmanagement based on worker councils, and the Israeli kibbutz system founded on direct democracy?

The social context of these theoretical systems and their practical experiences are very difficult and so are their immediate goals. One of the major goals of American theories of management is the maximization of effectiveness in terms of economic efficiency, performance, and human adjustment. The West European systems, particularly that in West Germany, were created mainly as a pragmatic reaction to the political and social conditions of these countries after World War II. The Yugoslav experience has its political roots in the struggle for independence, but was inspired mainly by Socialist ideology and its humanitarian goals of abolition of exploitation and personal authority and the attempt to eliminate alienation. The demands for worker control and self-management which gained a new importance in the West European labor movement after the stormy political events of May 1968 in France and fall 1969 in Italy also have a Socialist ideological base. The kibbutz system aims to realize the values of equality and democracy within collective communities that cover all areas of life. In the Yugoslav and kibbutz approaches, workers' participation in decision making is tied to the abolition of private property. While worker representation in management as practiced in West Europe is being carried out mainly in nationalized industries, it is also being carried out in some industries that are privately owned. Behavioral science theories of participative management, however, generally ignore the issue of ownership.

Participation and influence. Despite these definitional problems, participation in decision making does imply mutual influence by work groups in an organization resulting in joint, binding commitments. Workers' participation in decision making in industrial organizations, therefore, implies that workers as a group-or in sub-groups such as departments or work teams-

\footnotetext{
2 Chris Argyris, Integrating the Individual and the Organization (New York: Wiley, 1964); Warren G. Bennis, Changing Organizations (New York: McGraw Hill, 1966); Rensis Likert, New Patterns of Management (New York: McGraw Hill, 1961); Douglas McGregor, The Human Side of Enterprise (New York: McGraw Hill, 1960).
} 
take part in this process of mutual influence. However, there may be differences among systems in the areas of decision making in which workers participate. In some cases, participation may be confined to matters related to the immediate situation in the work group or department, while in others it may center around general plant issues or policies. (These types of participation are not necessarily mutually exclusive.)

While we expect that the possibility for workers to formally participate as a group through representation will actually enhance their influence, we do not exclude the possibility that in certain situations no real influence will occur, since workers' attempts to exercise influence may be overruled by other more powerful groups. In some cases, manipulative techniques may be used by management to create a feeling of participation without a real increase in workers' influence.

The hypothesis that workers' participation in decision making results in the actual exercise of influence by workers raises the question of the relationship between the influence of workers and the influence of other groups in the plant. One possible argument against participative management, for example, is that an increase in influence by workers may cause a corresponding decrease in influence by managers which, of course, is not an agreeable prospect for most managers. Some theorists, however, argue that participation need not lead to a decrease in managerial influence and that an increased amount of interaction connected with the process of mutual influence can result in a greater amount of total influence in the system. ${ }^{3}$ This thesis is supported by research reported by Lammers, Mulder, Seashore and Bowers, and Tannenbaum et al. ${ }^{4}$ In most of the cases observed, participation was associated with relatively high levels of total control or influence, while only in certain cases was it accompanied by a relatively equalitarian distribution of influence in the organization.

While a number of studies suggest that participation may be related to the total amount of control, the findings give no clear answer to how participation enhances influence in an organization. Assuming for the moment the existence of only two major groups in industrial organizations-workers and managerial personnel-the positive relationship between participation and total amount of control may occur through (1) an increase in worker influence accompanied by a decrease in management influence which, however,

\footnotetext{
${ }^{3}$ Likert, op. cit.; Rensis Likert, The Human Organization: Its Management and Value (New York: McGraw Hill, 1967); A. S. Tannenbaum, "Control Structure and Union Functions," American Journal of Sociology, LXI (May, 1956), 536-545.

${ }^{4}$ C. J. Lammers, "Power and Participation in Decision Making in Formal Organizations," American Journal of Sociology, LXXIII (September, 1967), 201-216; M. Mulder, "Power Equalization through Participation," Administrative Science Quarterly, XVI (March, 1971), 31-38; Stanley E. Seashore and David G. Bowers, "Durability of Organizational Change," American Psychologist, XXV (March, 1970), 227-233; A. S. Tannenbaum et al., Control in Organizations (New York: McGraw Hill, 1968).
} 
is less than the increase in the influence of workers, (2) an increase in workers' influence accompanied by no change in the amount of managerial influence, or (3) an increase in workers' influence accompanied by an increase in management's influence.

The possible contribution of participation to the influence exercised by management can be explained in at least two ways:

1. Participation may have a direct impact on managerial influence through an enhanced flow of communication among hierarchical levels. Improved information may improve the quality of managers' decisions and thus increase managerial influence in the organization.

2. Managerial influence may also be enhanced indirectly as a result of the increased influence of workers in the participative system. This effect on managerial influence may be due to (a) the favorable attitudes of workers toward management and trust by workers in the motives and actions of management (such attitudes and trust create conditions for the implementation of management influence), and (b) a rise in the workers' sense of responsibility in and identification with the organization (such responsibility and identification provide an important basis of control which Follett refers to as the "law of the situation"). ${ }^{5}$

A qualification might be added to this discussion of worker vs. managerial influence. Where strong antagonism exists between workers and management, workers' influence is not likely to contribute to the influence of managers. The influence of workers is more likely, under these circumstances, to be used in a power struggle and such influence may then be used to restrict the influence of management. But where workers and managers share, or feel they share, some common interest and where conditions of readiness for cooperation exist, influence by workers may contribute to the attainment of organizational goals and to the influence of management. Although the assumption of common interest applies more readily to some plants (like the kibbutz) than to others (like the Italian), we assume that it applies on the average to the plants in this study and that the general hypothesis connecting worker participation and influence therefore applies on the whole.

\section{Hypotheses} can be stated:

On the basis of the preceding discussion, several hypotheses

Hypothesis $I$. The degree of workers' participation in decision making in industrial organizations is related positively to the amount of total influence (control) in these organizations.

${ }^{5}$ H. Metcalf and L. Urwick, eds., Dynamic Administration, The Collected Works of Mary Parker Follett (New York: Harper, 1940). 
(This hypothesis assumes that the amount of influence in an organization is not fixed and workers' participation may enhance the influence of other groups.)

Hypothesis Ia. The degree of workers' participation in decision making is related positively to the amount of influence of workers as a whole.

Hypothesis Ib. The degree of workers' participation in decision making is related positively to the amount of managerial influence in an organization.

The following hypotheses concern the mediating factors between participation and managerial influence:

Hypothesis II. The frequency of communication between subordinates and superiors functions as an intervening variable between the degree of workers' participation in decision making and management's influence.

Hypothesis III. The amount of workers' influence functions as an intervening variable between the degree of workers' participation in decision making and the amount of managerial influence.

Two arguments were offered above concerning how workers' influence may enhance management's influence: (a) a rise in workers' influence may improve the organizational climate by contributing to a feeling of trust by members in management; (b) a rise in workers' influence may enhance members' sense of responsibility in the organization. Both effects-trust and responsibility-may enhance management's responsibility. The following hypothesis will test argument (a):

Hypothesis IV. Trust in management operates as an intervening variable between workers' influence and managerial influence.

The following two-part hypothesis will test argument (b):

Hypothesis Va. Sense of worker responsibility in the organization functions as an intervening variable between workers' influence and management's influence.

Hypothesis $\mathrm{Vb}$. The personal influence of each worker serves as an intervening variable between workers' influence as a whole and a worker's commitment to the organization.

\section{Research Design}

Ten plants confined to five industries-plastics, furniture, food processing, metal works, and foundries-were selected in each country. Plants were divided equally between small (35-100 persons) and large (164-1,496 persons) within each industry, except in kibbutzim where all plants are small. The average small plant ranges from 51 in Austria to 84 in Italy and Yugoslavia. The average large plant varies from 545 in Yugoslavia 
to 629 in Italy. ${ }^{8}$

Thirty-five persons, including individuals at each hierarchical level, were selected according to standardized procedures in each plant, making a total sample of 350 persons per country. Questionnaires were personally administered to each of the respondents (although a small percentage of the sampled persons refused to participate in the project or failed to answer some of the questions).

\section{Results}

Participation and influence. We shall first consider relationships between measures of participation and influence. The measure of workers' participation in decision making is based on the responses of members in each plant to the following questions:

1. Do workers participate in making important decisions related to their work?

2. Do workers participate in making important decisions related to general plant problems?

Each of these questions was answered on a four-point scale (ranging from "not at all" to "jointly decide"), and an average response within each plant of the two questions is taken as the measure of workers' participation in decision making as perceived by members.

Influence was measured by the following question: How much influence do the following groups or persons actually have on what happens in this plant? (Circle one number of each line across.)

(a) Plant manager and his executive board

(b) All other managerial and supervisory

(c) The worker as a group

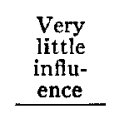

1

1

1

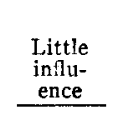

2

2

2

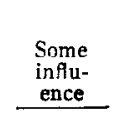

3

3

3

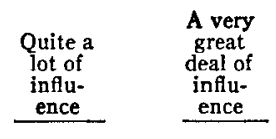

4

5

5

5

The measure of total control (influence) in each plant as perceived by members is based on an average of the responses to the above components by all of the respondents in each plant, and the control exercised by managers is based on an average of the responses to parts $a$ and $b$.

6 The design specified five large plants in each country exclusive of Israel. In fact, we were able to obtain one additional large foundry in Austria and the United States, and these additional plants enter into the following analyses. The number of large plants is, therefore, 22. 


\section{Findings}

The plants of the respective countries differ significantly in participation and influence according to the above measures. Table 1 shows the data for the small plants. Among the small plants, the kibbutz rank first on the measure of workers' participation in decision making, followed by the Yugoslav, Austrian, American, and Italian plants. This same ordering is found among the large plants (except that kibbutz plants are not included). The plants of the respective countries also differ in total amount of influence. Among the small plants, the American rank first, followed by the Yugoslav, kibbutz, Austrian, and Italian. The order is the same among the large plants (except that the kibbutz are not included). Thus, when the data are aggregated by country, there is some rough, although by no means perfect, correspondence between workers' participation in decision making and total amount of influence as reported by members.

TABLE 1

Mean Scores for Smal. Plants on Measures of Participation, INFLUENCE, AND OTHER VARIABLES

\begin{tabular}{lccccc}
\hline \hline & Italy & Austria & U.S. & Yugoslavia & Kibbutz \\
\hline 1. Worker participation & & & & & \\
$\begin{array}{l}\text { in decision making } \\
\text { ( Total amount of }\end{array}$ & 1.7 & 2.1 & 2.0 & 2.6 & 2.8 \\
influence & 3.2 & 3.2 & 3.8 & 3.6 & 3.6 \\
3. Workers' influence & 2.4 & 2.4 & 3.0 & 3.3 & 3.1 \\
4. Managers' influence & 3.6 & 3.6 & 4.2 & 3.7 & 3.8 \\
5. Personal influence & 2.0 & 2.2 & 2.7 & 2.8 & 2.4 \\
6. Superior-subordinate & & & & & \\
communication & 3.5 & 3.5 & 3.6 & 3.8 & 3.9 \\
7. Trust in management & 2.9 & 3.2 & 3.8 & 3.3 & 3.6 \\
8. Sense of responsibility & 2.8 & 3.2 & 3.9 & 3.8 & 3.6 \\
\hline
\end{tabular}

- The larger the score, the greater the amount of participation, influence, communication, etc. Differences between countries on each item are statistically significant at the .05 level or better with the possible exception of the item concerning communiration. The sample includes a substantial proportion of managerial and supervisory personnel as well as rank-and-file workers, although a majority of respondents in each country are rank-and-file workers. Differences between countries in measures of personal influence, trust, communication, and sense of responsibility, therefore, ought not be construed to mean differences among workers only. For differences between workers and managers in the respective countries, see Tannenbaum, Kavcic, Rosner, Vianello, and Weiser, Hierarchy and Ideology, A Cross National Comparison (forthcoming).

b Four-point scales were used to measure this item.

Participation and influence. Table 2 shows correlations between the measures relevant to Hypothesis I (degree of participation is related to total amount of influence). These correlations are based on the plant as the unit of analysis, averages for each plant serving as the measures for the plant. The correlations reflect differences among plants within countries as well as between, since the plants of all countries are placed into a single matrix. In general, the direction of relationships within countries corresponds to that 
between countries, but the number of plants per country is too small to permit comparisons of the relationships among countries.

The correlations are shown separately for small plants and large in order to maintain some degree of comparability. The column headed "all" is a simple average of the correlations among the small and large plants. Correlations that we estimate to be statistically significant at the .05 level are indicated ${ }^{?}$

TABLE 2

Correlations Between Workers' Participation nn Decision MaKing AND the INFLUENCE OF Groups in the Plant as Reported by Members

\begin{tabular}{llll}
\hline \hline & & Plants & \\
\cline { 2 - 4 } & Small & Large & All \\
\hline Participation and: & & & \\
Workers' influence & $.74^{\mathrm{a}}$ & $.51^{\mathrm{a}}$ & $.62^{\mathrm{a}}$ \\
Managers' influence & .20 & .38 & .29 \\
Total amount of influence & $.51^{\mathrm{a}}$ & $.85^{\mathrm{a}}$ & $.68^{\mathrm{a}}$ \\
\hline $\mathrm{a}$ p $<.05$ (see footnote 7 ). & & &
\end{tabular}

Plants that are reported to be highly participative are likely also to be characterized by a high total amount of influence, according to their members. The enhanced influence of workers in the participative plants may also be accompanied by increased influence among managers, although the positive correlation between participativeness and the influence of managers is not high (and not statistically significant according to our criterion). The major contribution to the enhanced influence in the participative compared to the nonparticipative plants appears to result from the greater influence of workers in the former plants compared to the latter. Some contribution to the enhanced influence may also come from managers, but this appears to be a smaller contribution than that of the workers, and the result is that the participative plants are somewhat more "power equalized" than the nonparticipative. This power equalization, however, does not mean a reduction in the control exercised by managers-managers, on the average, hold their own. Managers may not actually exercise more influence in the partici-

7 The nature of the sample does not permit a precise statistical evaluation of these correlations since we do not have a simple random sample of plants, which is the basis for conventional tests of significance. We assume that, because of the "clustered sample," the true degrees of freedom are lower than those based on the number of sampled plants under conditions of a simple probability sample. To compensate in some degree for the clustering by country, we assume that the effective number of cases is somewhere between the average number of plants per country and the total number of plants entering into a correlation, and we have selected the number half way between these extremes. Since all of the hypotheses are directional, one-tailed tests are employed. On the basis of the above assumptions, we calculate that correlations of $.39, .44$, and .31 are statistically significant at the .05 level among the small, large, and total sample of plants, respectively. These standards, however, are very approximate. 
pative plants compared to the less participative, but they are certainly not, on the average, less influential in the former compared to the latter.

Mediating factors. Hypotheses II and III refer to two possible explanations for the effect of workers' participation in decision making on managerial influence: (a) the frequency of communication between subordinates and superiors; (b) the amount of workers' influence. An intervening variable should correlate more highly with the independent variable and the dependent variable than the latter variables correlate with each other. We therefore consider three relationships, that between (1) the independent and the dependent variable, (2) the independent and the intervening variable, and (3) the intervening and the dependent variable. Table 3 shows these relationships in which communication was measured by the questions:

(a) How frequently do you speak to [your immediate subordinate] about work matters?

(b) How frequently do you speak to [your superior] about work matters? Answers were checked on a five-point scale and row 6 of Table 1 shows the mean scores in the respective countries.

TABLE 3

Correlations Between Pahticipation, Communication, and Managerial INFLUence as Reported by Members

\begin{tabular}{lclc}
\hline & & Plants & \\
\cline { 2 - 4 } & Small & Large & All \\
\hline $\begin{array}{l}\text { Participation and } \\
\text { managers' influence }\end{array}$ & .20 & .38 & .29 \\
$\begin{array}{l}\text { Participation and } \\
\text { communication }\end{array}$ & $.34^{\mathrm{a}}$ & $.46^{\mathrm{a}}$ & $.40^{\mathrm{a}}$ \\
$\begin{array}{c}\text { Communication and } \\
\text { managers' influence }\end{array}$ & $.41^{\mathrm{a}}$ & .37 & $.39^{\mathrm{a}}$ \\
\hline $\mathrm{a}^{\mathrm{p}}<.05$ (see footnote 7$)$. & & &
\end{tabular}

Communication between superiors and subordinates tends to be high where participation of workers in decision making is high, and in addition, communication seems to be related to the influence of managers. Communication might, therefore, serve as a link between the participation of workers and the influence of managers.

Table 4 shows the correlations in which workers' influence is considered as an intervening variable. Worker influence is not inconsistent with managerial influence, according to the reports of members. On the contrary, the influence of managers appears high where the influence of workers is high. It is possible, therefore, that the influence of workers may help to explain why managers in the relatively participative plants have as much (if not more) influence as (than) managers in the nonparticipative plants. 
Trust and responsibility. Table 5 presents data relevant to the hypothesis (IV) that trust in management serves as an intervening variable between the influence of workers and that of managers, and row 7 of Table 1 shows

TABLE 4

Correlations Between Participation and Influence of WORKERS AND MANAGERS AS REPORTED by MEMBERS

\begin{tabular}{lccc}
\hline & & Plants & \\
\cline { 2 - 4 } & Snall & Large & All \\
\hline $\begin{array}{l}\text { Participation and } \\
\text { managers' influence }\end{array}$ & .20 & .38 & .29 \\
$\begin{array}{l}\text { Participation and } \\
\quad \text { workers' influence }\end{array}$ & $.74^{\mathrm{a}}$ & $.51^{\mathrm{a}}$ & $.67^{\mathrm{a}}$ \\
$\begin{array}{l}\text { Workers' influence and } \\
\text { managers' influence }\end{array}$ & $.48^{\mathrm{a}}$ & .35 & $.41^{\mathrm{a}}$ \\
\hline " $\mathrm{p}<.05$ (see fotrote 7 ). & & &
\end{tabular}

the mean scores for small plants in the five countries. Trust in management was measured by the following questions:

1. Do you think the responsible people here have a real interest in the welfare of those who work here?

2. Do the responsible people in this plant improve working conditions only when forced to?

3. When a worker in this plant makes a complaint about something, is it taken care of?

Each of the above questions was answered on a five-point scale and the following, taken from Likert, ${ }^{8}$ was added to the above as part of an overall index of trust.

4. What do workers communicate to their superiors?

Answers were checked on the following scale (from 1 to 4 ):

they communicate all information accurately;

they communicate mainly what their superiors like to hear;

they communicate only what their superiors like to hear;

they distort all information.

TABLE 5

Corretations Between Trust and the Influence of Managers AND OF WORKERS AS REPOKTED BY MEMBERS

\begin{tabular}{|c|c|c|c|}
\hline & \multicolumn{3}{|c|}{ Plants } \\
\hline & Small & Large & All \\
\hline $\begin{array}{l}\text { Workers' influence and } \\
\text { managers' influence }\end{array}$ & $.48^{\mathrm{a}}$ & .35 & $.41^{\prime}$ \\
\hline $\begin{array}{l}\text { Workers' influence and } \\
\text { trust in managers }\end{array}$ & $.66^{*}$ & .31 & $.48^{\mathrm{a}}$ \\
\hline $\begin{array}{l}\text { Trust in management and } \\
\text { managers' influence }\end{array}$ & $.81^{*}$ & $.80^{n}$ & $.80^{\mathrm{a}}$ \\
\hline
\end{tabular}

8 Likert, New Patterns of Management. 
The very substantial correlations between trust in management and the influence of managers are consistent with the notion that trust by members may be an important basis upon which managers build influence.

Table 6 presents data relevant to the hypothesis (Va) that workers' sense of responsibility contributes to the influence of managers and that such responsibility intervenes between workers' influence and that of managers. Row 8 of Table 1 shows the mean scores for small plants in the respective countries. Responsibility was measured by the following question:

To what extent do you feel really responsible for the success of (your own work group.......? your department.......? the whole plant.......? Answers were checked on a five-point scale.

TABLE 6

Conaelations Between Workers' Sense of Responsibility and the Influence of Workers and Managers as Reported by Members

\begin{tabular}{lccc}
\hline \hline & & & Plants \\
\cline { 2 - 4 } & Small & Large & All \\
\hline $\begin{array}{l}\text { Workers' influence and } \\
\text { managers' influence }\end{array}$ & $.48^{\mathrm{a}}$ & .35 & $.41^{\mathrm{a}}$ \\
$\begin{array}{c}\text { Workers' influence } \\
\text { and responsibility }\end{array}$ & $.61^{\mathrm{a}}$ & .37 & $.49^{\mathrm{a}}$ \\
$\begin{array}{c}\text { Responsibility and } \\
\text { managers' influence }\end{array}$ & $.50^{\mathrm{a}}$ & $.68^{\mathrm{a}}$ & $.59^{\mathrm{a}}$ \\
\hline $\mathrm{p}<.05$ (see footnote 7). & & &
\end{tabular}

These correlations are reasonably consistent with the notion that the influence of workers contributes to a sense of responsibility and that this responsibility increases the sensitivity and amenability of workers to the influence attempts of managers.

Personal influence and sense of responsibility. Table 7 shows correlations relevant to the hypothesis $(\mathrm{Vb})$ that the personal influence of workers serves as an intervening variable that might explain the relationship between the influence of workers as a group and the sense of responsibility felt by workers. Personal influence was measured by the question:

How much influence do ... [you, personally] actually have on what goes on in this plant?

Table 1 , row 5 , shows the mean scores for the small plants.

The very substantial correlations between the personal influence which workers feel in these plants and their sense of responsibility adds credence to the notion that personal influence enters into the chain that helps explain how the influence of workers as a group may enhance the influence of managers. 


\section{Conclusions}

Figure 1 shows graphically the correlations among the variables which are part of the argument that workers' participation may enhance (or at least need not reduce) the influence of managers. Participation in decision making by workers has a direct bearing on the influence of workers as a group, which has implications in turn for the personal influence, trust, and responsibility felt by individual workers. Where workers trust

TABLE 7

CORRELATIONS BETWEEN WORKERS' SENSE OF RESPONSIBILITY AND THE INFLUENCE OF WORKERS

\begin{tabular}{|c|c|c|c|}
\hline & \multicolumn{3}{|c|}{ Plants } \\
\hline & Small & Large & All \\
\hline $\begin{array}{l}\text { Workers' influence } \\
\text { and responsibility } \\
\text { Workers' influence and }\end{array}$ & $.61^{\mathrm{a}}$ & .37 & $.49^{a}$ \\
\hline $\begin{array}{c}\text { personal influence } \\
\text { Personal influence and }\end{array}$ & $.82^{\mathrm{a}}$ & $.45^{\mathrm{a}}$ & $.63^{\mathrm{a}}$ \\
\hline sense of responsibility & $.72^{\mathrm{a}}$ & $.82^{\mathrm{a}}$ & $.77^{\mathrm{a}}$ \\
\hline
\end{tabular}

\section{FIGURE 1}

Correlations Between Workers' Participation in Decision Making and Reactions of Members That Are Related to the Influence of Managers (Small Plants)

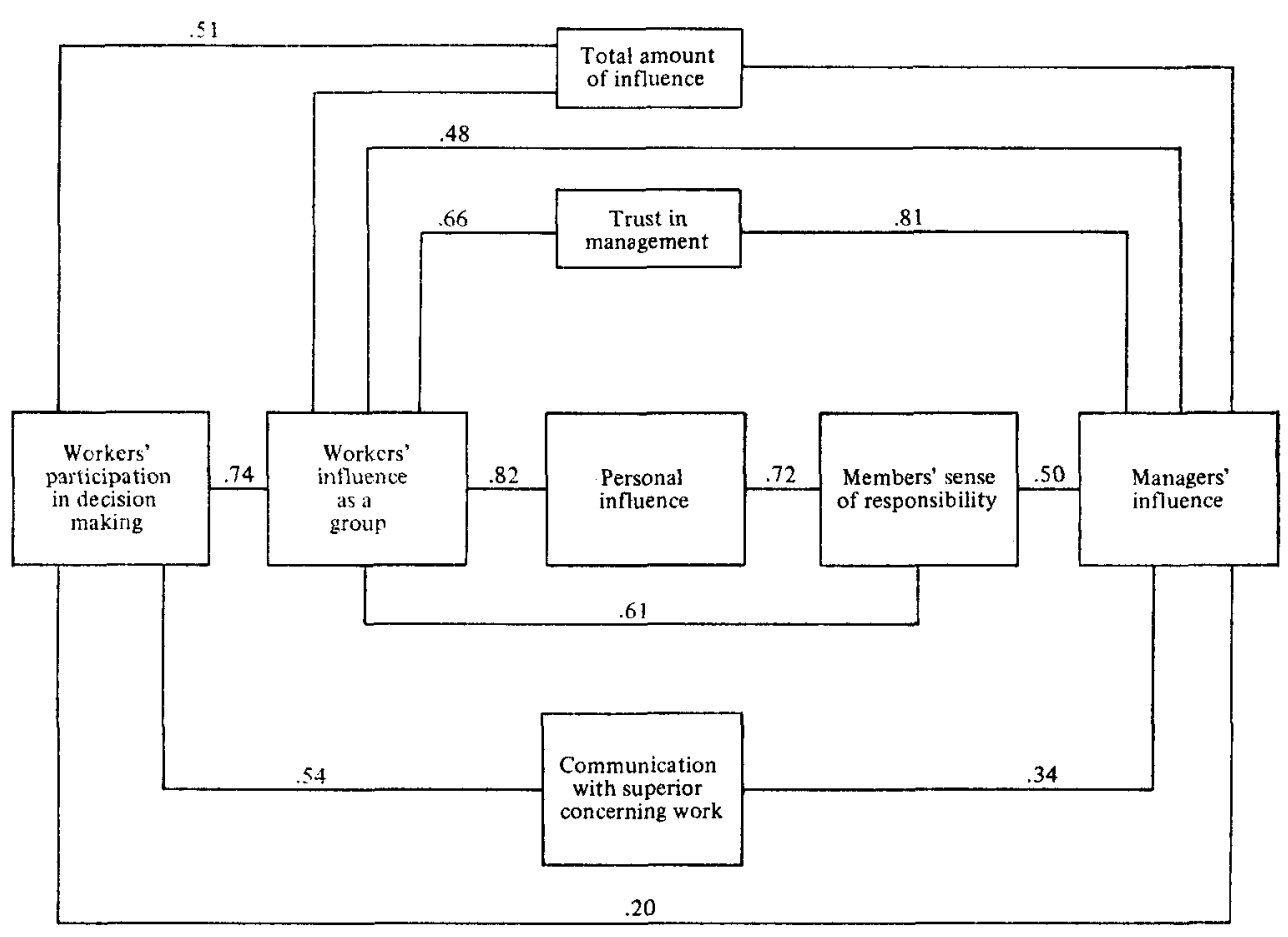


212 / M. ROSNER, et al.

management and where they feel a sense of responsibility in the plant, they are likely to be responsive to the influence attempts of managers, and managers are thus likely to be influential under these conditions. Plants where workers participate in decisions tend, therefore, to be characterized by a relatively high level of control, according to members. The enhanced influence of workers under these conditions does not have the effect of reducing the influence of managers since the trust and responsibility felt by members provide a basis for sustaining the influence of managers if not increasing it. 